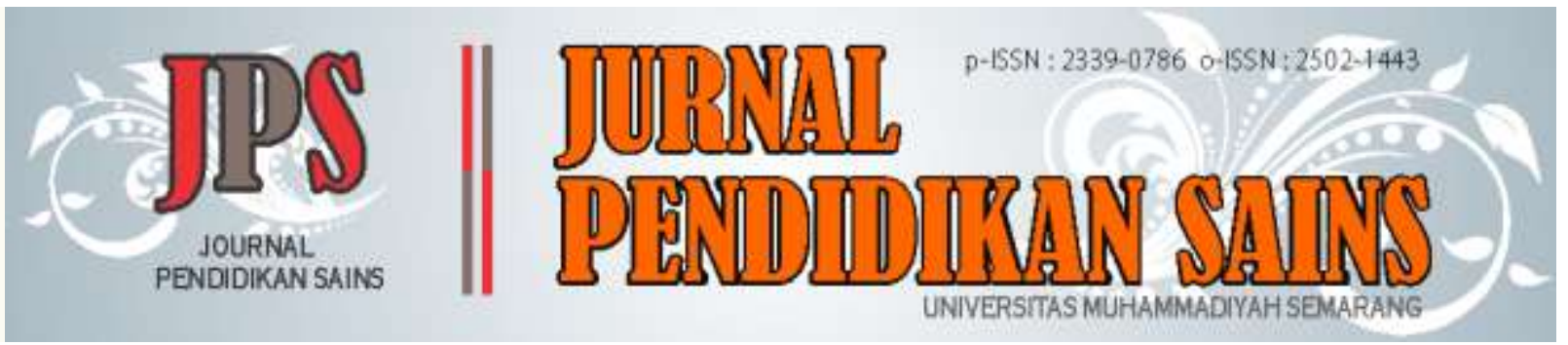

\title{
The Effect of Agrosains Based Engineering Design Process Learning Model With A STEM Approach to SMP Student
}

\author{
Anjar Putro Utomo ${ }^{a, 1, *}$, Dyah Intan Prismasari ${ }^{b, 2}$, Erlia Narulita $^{\mathrm{c}, 3}$ \\ ${ }^{a}$ Study Program of Science Education, Faculty of Teacher Training and Education, University of Jember, Jl. Kalimantan No. 37, \\ Jember, Jawa Timur 68121 \\ ${ }^{\mathrm{b}}$ Study Program of Science Education, Faculty of Teacher Training and Education, University of Jember, Jl. Kalimantan No. 37, \\ Jember, Jawa Timur 68121 \\ ${ }^{c}$ Study Program of Science Education, Faculty of Teacher Training and Education, University of Jember, Jl. Kalimantan No. 37, \\ Jember, Jawa Timur 68121 \\ ${ }^{1}$ anjar_pu.fkip@unej.ac.id *; ${ }^{2}$ dyahintan62@gmail.com; ${ }^{3}$ erlia.fkip@unej.ac.id \\ * corresponding author
}

\begin{tabular}{ll}
\hline \multicolumn{2}{l}{ Article history } \\
\hline Submission $\quad: 2020-08-10$ \\
Revised $\quad: 2021-01-22$ \\
Accepted $\quad: 2021-03-08$ \\
\\
Keyword \\
\hline HOTS Junior High Students \\
EDP Model \\
STEM Approach
\end{tabular}

\begin{abstract}
This research aims to study the effect of an agriscience-based engineering design process learning model with a STEM approach to junior high school students' Higher Order Thinking Skills. The research type is quasi-experiment with pre and post-test control group design. This research was done in the semester of 2019/2020 school year. The subject of this research is 7th-grade students. Data collection techniques and instruments were tested, which included the revised HOTS Bloom Taxonomy indicator. Kolmogorov Smirnov normalization test, independent sample t-test, and normalized gain were used to analyze the data. The result of the independent sample t-test was Sig. $(2$-tailed $)=0.000<$ sig. a $=$ 0.05 . Student's HOTS improvement in experiment class was higher $(\mathrm{N}$-gain $=$ $0.494)$ than control class $(\mathrm{N}$-gain $=0.279)$. Based on the result, it can be concluded that there is a significant effect from agroscience-based engineering design process learning model with stem approach to junior high school student's HOTS. The HOTS improvement student class experiment was in the middle category.
\end{abstract}

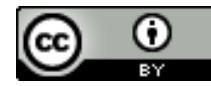

This work is licensed under a Creative Commons Attribution 4.0 International License C2021 Jurnal Pendidikan Sains Universitas Muhammadiyah Semarang

\section{INTRODUCTION}

The achievement of Indonesian students' scores on TIMSS since its inception in 1995 has always been below the international average score (Martin et al., 2001, 2004, 2008, 2012), especially in TIMSS 2011 Indonesia is in the third lowest rank with an achievement of a score of 406 while on average. The international average score is 500 (Martin et al.,
2012). The ability of Indonesian students to work on the reasoning domain questions in the field of science in TIMSS is still low (Rofiah et al., 2018). Analyzing, integrating, hypothesizing, designing, drawing conclusions, generalizing, evaluating, and justifying are abilities needed to work on reasoning domain problems (Martin et al., 2012). These abilities are grouped into analyzing, evaluating, and 
DOI: https://doi.org/10.26714/jps.9.2.2021.120-125

creating, components of Higher Order Thinking Skills (HOTS) (Utomo et al., 2018). A low reasoning domain value indicates a low student HOTS.

The low HOTS of students is caused by the application of science learning, which emphasizes the aspect of memorization alone (Nofiana, 2017). The learning carried out is still teacher-centered (Sofyan, 2019). To compete in the 21 st century, students need to have HOTS (Ramadhan et al., 2017). HOTS is the ability to think critically, logically, reflectively, and creatively (Scott, 2015) by involving various thought processes that are applied to complex situations to make solutions to solve a problem (King et al., 2015). One of the efforts to stimulate HOTS improvement is applying the Science, Technology, Engineering, Mathematics (STEM) approach in learning (Bunyamin and Finley, 2016: Yusuf and Widyaningsih, 2018).

The STEM approach is an approach that integrates the two or more disciplines of STEM (science, technology, engineering, and mathematics) in learning (Becker and Park, 2011). The STEM approach requires students to actively participate in learning that involves hands-on and mind-on activities to solve a problem in the context of everyday life (Rohmah et al., 2019). Applying the STEM approach in learning can be done with a learning model (Permanasari, 2016).

Engineering Design Process (EDP) is a learning model based on the power of designing solutions to problems (Trilling and Fadel, 2009). EDP has several stages: define, learn, plan, try, test, and decide (Berg and Dunlap, 2017). The application of the EDP model can be complemented by agricultural elements (application of scientific principles in agriculture) as a context in science learning. The agricultural element links learning in the classroom with what students encounter in everyday life and encourages students to take an active role in the learning process to influence the increase in student HOTS. Sugiarti and Bija (2012) state that the context or phenomenon that is very influential in science learning is the context or phenomenon that exists in the surrounding environment so that learning becomes contextual.

Based on the description above, experimental research was conducted with "The
Effect of Agriscience-Based Engineering Design Process Learning Model with STEM Approach on Higher Order Thinking Skills of Junior High School Students."

\section{METHOD}

Types of research

This study used a quantitative approach with the experimental research method type quasi-experimental design.

Time and Place of Research

This research was conducted at SMP Negeri 1 Puger, located in Jember Regency, East Java, in the even semester of the 2019/2020 school year.

\section{Research Targets / Subjects}

The population in this study were students in grade 7 consisting of classes $7 \mathrm{~A}$, 7B, 7C, 7D, and 7E who were assumed to have the same abilities. The samples were determined by taking two classes randomly. The samples of this research were 7A students (32 students) as the control class and 7B students (31 students) as the experimental class.

Procedure

The research design used pre and posttest control group design (Creswell, 2014).

\begin{tabular}{|llll|}
\hline Group A & $O_{1}$ & $X$ & $O_{2}$ \\
Group B & $O_{3}$ & & $O 4$ \\
\hline
\end{tabular}

Group A: Experiment group

Group B: Control group

$\mathrm{Ol}=\mathrm{O} 3 \quad:$ Pre-test

$\mathrm{O} 2=04 \quad:$ Post-test

$X$ : Treatment in the experimental group (learning uses the EDP learning model based on Agriscience with the STEM approach).

Data, Instruments, and Data Collection Techniques

Student HOTS data were measured before (pre-test) and after (post-test) learning was carried out. The data collection instrument was a multiple-choice test which included HOTS Taxonomy Bloom indicator revision (analyzing, evaluating, creating) that the validator has validated. Examples of items used in the study are presented in Table 1 below. 
Table 1. Examples of items used in the study

Question HOTS level

Grade $7 \mathrm{G}$ students have the assignment to make a water purifier made of large stones, cotton, fibers, and small stones. One group made a design with the arrangement of placement of these Evaluating(C5) materials as follows from top to bottom:

\begin{tabular}{c}
\hline Cotton \\
\hline Palm fiber \\
\hline Big Stone \\
\hline Small stone \\
\hline
\end{tabular}

Do you think that the order in which the ingredients are placed can effectively purify polluted water?

An a. yes, small stones are placed in the lowest order because they can filter out the fine impurities that pass through the filtering of the material above.

b. no, the cotton should be placed at the bottom of the order to filter out the most minor and more acceptable components.

c. yes, large boulders are placed right on top of small stones so that small stones can filter out the dirt that escapes from the large stone sieve quickly.

d. yes, cotton is placed right on the top because it can filter large and small dirt so that no dirt passes through the filter.

Data analysis technique

Data analysis used normalized gain test and independent-sample t-test after first doing the normality test Kolmogorov-Smirnov using the SPSS v.24 programs.

The normality test is carried out as a prerequisite test before the independent sample t-test parametric test. The independent sample ttest used the post-test scores of the experimental class and the control class to determine whether or not there was a significant effect of applying the EDP model with the STEM approach to the HOTS of junior high school students. The provisions in the independent sample t-test, namely if $\mathrm{p} \mathrm{(2-}$ tailed) $>0.05$, then there is no significant effect, and if $\mathrm{p} \leq 0.05$, then there is a significant effect (Riyanto and Hatmawan, 2020). Meanwhile, to identify the increase in student HOTS, a normalized gain ( $\mathrm{N}$-gain) test was carried out (Herlanti, 2014), with high criteria if the $\mathrm{N}$ gain $\geq 0.70$, being if $0.30 \leq \mathrm{N}$-gain $\leq 0.70$, and low if N-gain <0.30 (Hake, 2002).

\section{RESULTS AND DISCUSSION}

Data normality test results The HOTS of the experimental and control class students are presented in Table 2 below.

Table 2. Normality Test Results Pre-test and post-test for the experimental class and control class

\begin{tabular}{|c|c|c|}
\hline \multicolumn{3}{|c|}{ Kolmogorov-Smirnov Test } \\
\hline & & HOTS Students \\
\hline \multicolumn{2}{|c|}{$\mathrm{N}$} & 126 \\
\hline \multirow[b]{2}{*}{ Normal Parametersa, b } & Mean & 62.53 \\
\hline & Std. Deviation & 16,149 \\
\hline \multirow{3}{*}{ Most Extreme Differences } & Absolute & .062 \\
\hline & Positive & .062 \\
\hline & Negative & -.059 \\
\hline \multicolumn{2}{|c|}{ Statistical Test } & .062 \\
\hline \multicolumn{2}{|c|}{ Asymp. Sig. (2-tailed) } & $.200 \mathrm{c}, \mathrm{d}$ \\
\hline
\end{tabular}


Table 3. Results of the Student's HOTS Independent Sample t-test

\begin{tabular}{cccccc}
\hline \multicolumn{4}{c}{ Levene's test } & T-test \\
\hline F & Sig. & T & DB & $\begin{array}{c}\text { Sig. }(2- \\
\text { tailed })\end{array}$ \\
\hline
\end{tabular}

\begin{tabular}{|c|c|c|c|c|c|c|}
\hline \multirow{3}{*}{$\begin{array}{c}\text { HOTS } \\
\text { Students }\end{array}$} & $\begin{array}{l}\text { Assumption of } \\
\text { the same } \\
\text { variant }\end{array}$ & \multirow{3}{*}{.183} & \multirow{3}{*}{.670} & 3,934 & 61 & .000 \\
\hline & & & & & & \\
\hline & $\begin{array}{l}\text { Assumption of } \\
\text { unequal } \\
\text { variants }\end{array}$ & & & 3,937 & 60,995 & .000 \\
\hline
\end{tabular}

Based on Table 3, it can be seen that the test result of the independent sample t-test is Sig. $(2$-tailed $)=0.000<$ sig. $\alpha=0.05$. The result shows a significant effect of applying the Agriscience-based EDP learning model with the STEM approach to the HOTS of junior high school students. This is in line with the research of Bunyamin and Finley (2016); Yusuf and
Widiyaningsih (2018), where applying the STEM approach in learning affects students' HOTS.

Then to find out the increase and category of improvement, The students' HOTS was tested for $\mathrm{N}$-gain. The results of the $\mathrm{N}$-gain test are presented in Table 4 below.

Table 4. Test Results N-gain Student HOTS

\begin{tabular}{ccccc}
\hline \multirow{2}{*}{ Class } & \multicolumn{3}{c}{ Average } & \multirow{2}{*}{ Criteria } \\
\cline { 2 - 4 } & Pre-test & Post-test & N-gain & \\
\hline Control & 50.84 & 64.88 & 0.28 & Low \\
\hline Experiment & 56.55 & 78.16 & 0.49 & Moderate \\
\hline
\end{tabular}

Based on the results of the N-gain test, it can be seen that the HOTS increase of the experimental class students (moderate criteria) is higher than the control class (low criteria). The acquisition of these values shows that learning through the EDP learning model with the STEM approach can better stimulate student HOTS.

Learning using EDP requires students to analyze problems in detail and critically, where the teacher guides students in understanding the main points of the problem (Li et al., 2016)-learning in the experimental class using the EDP model trains students in designing solutions based on the results of problem analysis which are then manifested in making solutions that have been designed. Making something that starts with making the design first can help improve student HOTS (Ichsan et al., 2018).

Implementing the EDP model combined with elements of Agriscience as a learning context can increase student HOTS because the agricultural element links learning in class with what students encounter in everyday life and encourages students to take an active role in the learning process.

Applying the STEM approach in this study can strengthen each stage of learning with Agriscience-based EDP in facilitating students to build their knowledge in an integrated manner in science, technology, engineering, and mathematics where this integration is not found in learning in the control class. This is in line with the results of research conducted by Yusuf and Widiyaningsih (2018) that applying the STEM approach in learning has a significant effect on increasing student HOTS.

Based on the study results, the increase in student HOTS in the experimental class was due to the application of the EDP model based on Agriscience with the STEM approach. The STEM approach in learning provides space for students to actively identify problems, look for, investigate, and find their answers to existing problems.

Analysis HOTS of experimental class students on each indicator is done by identifying the number of students who can answer correctly or incorrectly on the pre-test and post-test. At the same time, the 
Table 5. Identification of students' answers to each question indicator

\begin{tabular}{|c|c|c|c|c|c|}
\hline \multirow{2}{*}{ Indicator } & \multirow{2}{*}{ Type } & \multicolumn{2}{|c|}{ Pre-test } & \multicolumn{2}{|c|}{ Post-test } \\
\hline & & correct & wrong & correct & wrong \\
\hline \multirow[t]{3}{*}{ Analyzing } & Type 1 & 27 & 4 & 26 & 5 \\
\hline & Type 2 & 27 & 4 & 27 & 4 \\
\hline & Type 3 & 22 & 9 & 15 & 16 \\
\hline \multicolumn{2}{|c|}{ Average } & 25 & 6 & 23 & 8 \\
\hline \multirow[t]{3}{*}{ evaluating } & Type 1 & 14 & 17 & 30 & 1 \\
\hline & Type 2 & 6 & 25 & 21 & 10 \\
\hline & Type 3 & 24 & 7 & 25 & 6 \\
\hline \multicolumn{2}{|c|}{ Average } & 15 & 16 & 25 & 6 \\
\hline \multirow[t]{3}{*}{ creating } & Type 1 & 29 & 2 & 31 & 0 \\
\hline & Type 2 & 23 & 8 & 26 & 5 \\
\hline & Type 3 & 26 & 5 & 30 & 1 \\
\hline \multicolumn{2}{|c|}{ Average } & 26 & 5 & 29 & 2 \\
\hline
\end{tabular}

Based on Table 5, it can be seen that on average, students who cannot answer correctly (answer wrongly) to the questions pre-test analyzing indicator (C4) is 6, evaluating (C5) is 16, and creating (C6) is 5 . Based on these results, it is known that the highest ability possessed by students is creating, while the lowest ability is evaluating.

On the question post-test mean of students who cannot answer correctly (answer incorrectly) on the analyzing indicator (C4) is 8 , evaluating (C5) is 6 , and creating (C6) is 2 . Based on these results, it is known that the highest ability students have is creating, while the lowest ability is analyzing.

The pre-test and post-test results are different from the research of Astuti and Adirakasiwi (2019). The result explains that with a high cognitive level that is an indicator of HOTS, students will experience difficulties in solving HOTS-type questions. On average, students who cannot answer with true (answer wrong) are high. This can happen because the test questions used to measure students' HOTS are not tested for reliability first, so the reliability of these questions is unknown. Utomo et al. (2018) stated that the validity and reliability test greatly determines the reliability of the questions made.

\section{CONCLUSION}

\section{Conclusions}

Based on the study results, it can be concluded that the EDP learning model based on Agriscience with the STEM approach has a significant effect in increasing student HOTS with an N-gain value of 0.494 , which belongs to the moderate improvement category. The students' creating ability in the pre-test and post-test was higher than the evaluating and analyzing abilities.

Suggestion

For further researchers with the same topic, it is hoped that they can test the reliability of the test instruments used.

\section{ACKNOWLEDGMENT}

Thanks to all those who helped in this research.

\section{REFERENCES}

Astuti, N., and AG Adirakasiwi. (2019). Analysis of the difficulties of junior high school students in solving HOTS (higher-order thinking skills) questions. Proceedings of the National Seminar on Mathematics and Sesiomadika Mathematics Education. Singaperbangsa Karawang University.

Berg, K., and S. Dunlap. (2017). EngrTEAMS: Engineering to Transform the Education of Analysis, Measurement, and Science in a Team-Based Targeted Mathematics-Science Partnership. Ecuadorian Fishermen Grades 6-8. University of Minnesota \& Purdue University Research Foundation.

Bunyamin, MAH, and F. Finley. STEM education in Malaysia: reviewing the current physics curriculum. (2016). In International Conference of Association for Science Teacher Education, January 2016: $1-16$. 
Creswell, JW (2014). Research Design (Qualitative, Quantitative, and Mixed Methods Approaches). California: SAGE Publications.

Hake. (2002). Relationship of Individual Student Normalized Learning Gains in Mechanic with Gender, High School Physics, and Pretest Score on Mathematics and Spatial Visualization. [On line]. Accessed from HTTP: //www.physics.Indiana/edu/-hake.

Herlanti, Yanti. (2014). Questions and Answers Regarding Science Education Research. Jakarta: Syarif Hidayatulah University. ISBN 978-602017290-3-8.

Ichsan, IZ, E. Irani. FMHermawati. (2018). Increase in higher-order thinking skills in elementary school students through videos based on environmental pollution cases. Edubiotic. 3 (2): 12- 18. EISSN: 2597-9833.

King, FJ., L. Goodson., And F. Rohani. (2015). Higher Order Thinking Skills. Tallahassee, FL: Florida State University.

Li, Y., Huang, Z., Jiang, M., and Chang, TW (2016). The Effect on Pupils' Science Performance and Problem-Solving Ability through Lego: An Engineering Design-based Modeling Approach. Educational Technology \& Society. (19) 3: 143-156.

Martin, MO, Mullis, IVS, Gonzalez, EJ, Gregory, KD, Smith, TA, Chrostowski, SJ, Garden, RA, and O'Connor, KM (2001). TIMSS 1999 international results in science. Chestnut Hill, MA: TIMSS \& PIRLS International Study Center, Boston College.

Martin, MO, Mullis, IVS, Gonzalez, EJ, \& Chrostowski, SJ (2004). TIMSS 2003 international results in science. Chestnut Hill, MA: TIMSS \& PIRLS International Study Center, Boston College.

Martin, MO, Mullis, IVS, and Foy, P. (with Olson, JF, Erberber, E., Preuschoff, C., \& Galia, J.). (2008). TIMSS 2007 international results in science. Chestnut Hill, MA: TIMSS \& PIRLS International Study Center, Boston College.

Martin, MO, Mullis, IVS, Foy, P., and Stanco, GM (2012). TIMSS 2011 international results in science. Chestnut Hill, MA: TIMSS \& PIRLS International Study Center, Boston College.

Nofiana, M. 2017. The profile of science literacy skills of junior high school students in the city of Purwokerto is viewed from content, process, and scientific context. Journal of Social Science and Humanities. 1 (2): 77-84.

Permanasari, Anna. (2016). STEM education: innovation in science learning. National Seminar on Science Education (SNPs), Surakarta. 22 October 2016. 23-34.

Ramadhan, F., S. Mahanal., And S. Zubaidah. (2017). Ability to ask class X students of Batu City private high school in Biology lessons. Bioeducation Journal of Biology Education. 8 (1): 11-15.

Riyanto, S., and Hatmawan, AA (2020). Quantitative Research Research Methods: Research in the Field of Management, Engineering, Education and Experiments. Yogyakarta: Deepublish.

Rofiah, E., NS Aminah., And W. Sunarno. (2018). Develop a science learning module based on highorder thinking skills (HOTS) to improve the critical thinking skills of grade VIII students of SMP / MTs. Inquiry: Journal of Science Education. 7 (2): 285-296.

Rohmah, UN, YZ Ansori., DS Nahdi. (2019). STEM Learning Approach in Improving Science Literacy Ability of Elementary School Students. Proceedings of the National Education Seminar, FKIP UNMA. 8 August 2019. 472-478.

Scott, CL (2015). The Futures Of Learning 2: What Kind of Learning For The 21st Century. Education Research and Foresight: UNESCO.

Sofyan, FA (2019). HOTS implementation in the 2013 curriculum. Journal of Inventa. 3 (1): 1-17.

Sugar., And S. Bija. (2012). The influence of the contextual learning model on the critical thinking skills of class XI IA SMA Negeri 3 Watansoppeng. Chemical Journal. 3 (1): 77-83.

Trilling, B., and Fadel, C. (2009). 21st Century Skills: Learning for Life in Our Times (san Francisco: John Wiley \& Sons).

Utomo, AP, E. Narulita., K. Shimizu. (2018). Diversification of reasoning science test items of TIMSS grade 8 based on higher-order thinking skills: a case study of Indonesian students. Journal of Baltic Science Education. 17 (1): 152-161.

Yusuf, I., and SW Widyaningsih. (2018). HOTS profile of physical education students in STEM-based classes using PhET media. Journal of Physics: Conf series. 1157 (2019) 032021. 